Check for updates

1 Loughborough University, UK

2 UCL Centre for Behaviour Change, UK

3 University of Sussex, UK

4 University College London, UK

5 London School of Hygiene \& Tropical Medicine, UK

6 University of St Andrews, UK

Cite this as: BMJ 2022;376:0575 http://dx.doi.org/10.1136/bmi.0575 Published: 03 March 2022

\section{What can we learn from the language of "living with covid"?}

\author{
Elizabeth Stokoe, ${ }^{1}$ Savannah Simons, ${ }^{2}$ John Drury, ${ }^{3}$ Susan Michie, ${ }^{4}$ Melissa Parker, ${ }^{5}$ Ann Phoenix, ${ }^{4}$ \\ Stephen Reicher, Bishop Wardlaw, ${ }^{6}$ Robert West ${ }^{4}$
}

Since the start of the covid-19 pandemic, in the UK and elsewhere, the phrase "living with covid"-and variations such as "live with it," "learning to live with the virus"-has circulated in public discourse. It refers to, and summarises, increasingly polarised positions with regards to the pandemic: on the one hand, accept the virus and resist adaptations; on the other, adopt mitigations and adapt to a new normal. Since the same phrase is used by different parties with diverse stakes and interests, it is emblematic of the way pandemic discourse has dichotomized over the past two years.

The start of 2022 saw a heavy emphasis on "living with it" in media and political discourse, with the different stances clear. For example, on 1 January 2022, in an article focused on medical solutions (vaccine, testing, anti-viral treatments) and the need to avoid "curbs on our freedom," the secretary of state for health and social care, Sajid Javid said, "we must try to live with covid." "Three days later in the Financial Times, another article focused more on learning: "Planning for a permanent pandemic, rather than pretending it does not exist, is what learning to live with the virus really means."2 Illustrating the different positions together, the secretary of state for levelling up, housing and communities, Michael Gove, said on 11 January that "the country had to learn to "live with covid"' and "admitted he was wrong to advocate within government for further restrictions."3

Last week, on 21 February 2022, the prime minister turned the "living with covid" phrase into the title of a formal statement to the House of Commons to articulate the UK government's current strategy. ${ }^{4}$ The two positions in the rhetorical battle over what "living with covid" means-politically, personally, and practically-are further apart than ever (e.g., two articles in The Telegraph on 18 February 2022: “'Gung-ho' living with covid strategy could backfire...”; "Time to move on from covid for good: The point of living with covid is that individuals should make their own minds up..." ${ }^{6}$ ). We argue that we need to move past clichéd phrases if we are to achieve a less binary and more productive point of connection.

\section{How covid became the object of "living with it"}

Since its first recorded use in 1951, the object of the phrase-the noun, or the "something" to be lived with-has been almost exclusively negative or problematic (e.g., "Living with it for years, in silent suffering"). ${ }^{7}$ Pre-covid uses of "living with the virus" were, of course, associated with HIV/AIDS, and "living with it" occurred in positive reports about medical interventions to prolong life. Other common uses referred more generally to disease and illness or death and pain (e.g., death of a child), as well as poor economic conditions (e.g., rampant inflation, interest rates) and environmental problems (e.g., low water levels, the world's weather patterns). Clearly, it is different to (learn to) live with individual situations (e.g., grief, death, cancer, Parkinson's Disease) than to live with things that are societal and structural situations (e.g., climate crisis, economic conditions).

From the start of 2020, the predominant object of "living with it" became covid-19. ${ }^{7}$ In February and March 2020, the earliest media mentions compared the acceptance of covid mortality to that of other disease mortality (flu, common cold, malaria, cancer). ${ }^{7}$ While most mentions were negative, some were in the context of constructive and optimistic descriptions of "learning": helping, adapting, and embedding protective measures into a "new normal," particularly in countries like Singapore and Australia. ${ }^{7}$ Other mentions were in the context of normalising in a vague way, often dismissing the reality of covid, giving up on adaptations, accepting the spread of the virus and its unspecified implications. Gradually, "living with covid" crept into both zero covid and covid denial discourse.

\section{Idiomatic phrases like "living with it" are powerful} rhetorical tools

Idiomatic phrases like "living with something" get traction and rhetorical power because they are already a trope or a catchphrase. " "Living with X" is used as part of everyday language and applied to myriad situations. In British English, to "live with something" means "to accept or continue in a situation that is difficult or unpleasant. ${ }^{9}$ Synonyms include to bear with something; to endure it; to suffer it; to accept it; to be resigned to something; to tolerate it; to face up to something unpleasant. ${ }^{10}$

In everyday language, idioms are often used to close down a topic, end arguments, or otherwise disengage from further debate. ${ }^{11}$ So, phrases like "you've just got to live with it." get uttered with exasperation in an attempt to end a conversation. Idioms also appear in the context of disputes and complaints, and "have a special robustness which lends them the function of summarising the complaint" to bring it to a close. ${ }^{12}$ In the context of covid, "live with it" often appears as the take-home message in the final line of newspaper articles (e.g., "Covid is here to stay, we just need to carry on as normal and learn to live with it"). ${ }^{13}$

Crucially, phrases like "live with it" are used as "rhetorically self-sufficient" or standalone "clinched-it" statements. ${ }^{14}$ The "clinched-it" quality of "live with it" is supported by the inclusion of other 
grammatical and lexical features such as "just," "simply," "need/have/got to," "must." In terms of "living with covid," the phrase has become parodied and satirical (e.g., "We've just got to learn to live with Boris Johnson") or scare-quoted as a position to be accepted or challenged (e.g. "'living with covid' idiocy”). ${ }^{15} 16$

We also note that the subject of the phrase, the "who" is learning to live with it (e.g., "'you," "we," or who "we" refers to) is often unspecified or opaque. The fact that the "we" in "we need to live with it" generally refers to a whole population or nation also shows how, as with other uses of self-sufficient arguments, inequalities are baked into the phrase. ${ }^{17}$ "We" are not all in the same position with regards to the physical, economical, and psychological resources to "live with it."

\section{What can we learn from "learning to live with covid"?}

As noted at the start of this article, a common variation on the "live/living with it" phrase is "learn/learning to live with it." But up to the start of 2022, media mentions of the "live with it" version of the phrase far outpaced the "learn/ing" version. ${ }^{7}$ This is not surprising in the context of the UK Government's "living with covid-19" strategy published last week with plans to remove "the remaining legal restrictions" and away "from government restrictions to personal responsibility."18 19

Of course, since the pandemic began, we have learned a lot about how to "live with covid," by which we mean live relatively safely while the virus circulates at high rates. We have learned about the importance of clean air and which masks are effective. We know more about the importance of clear, trusted, and consistent messaging and of adapting messages to specific contexts and audiences. We have learned new ways of assisting those who are clinically vulnerable, and supporting people physically and financially. Finally, we have learned the importance of reducing inequalities and the need for international cooperation as we learn across the globe about how to live with covid. The challenge now is to cut through clichéd and binary uses of "living with covid" as "common sense" about which "no more need be said" to a more productive point of connection that promotes "learning" above "just living with it."20

Competing interests: The authors are are all members of Independent SAGE Behaviour Group. SM, RW, JD, SR participate(d) in SAGE SPI-B and LS participated in the Policing and Security subgroup of SPI-B

\section{Provenance and peer review: not commissioned, not externally peer reviewed}

"Revellers wake up with a hangover after partying into 2022 in restriction-free England - but Sajid Javid offers a pick-me-up by revealing tighter rules are unlikely 'because we must live with Covid' despite UK recording 189,846 cases", MailOnline, January 1, 2022, Saturday 8:14 AM GMT.

2 "To live with Covid, we must plan for a permanent pandemic", FT.com, January 4, 2022, Tuesday.

3 Ministers optimistic on end of Covid curbs; Pandemic Vaccine passports and masks tipped to go in England as cases fall”, Financial Times (London, England), January 11, 2022 Tuesday, Edition 1, National Edition.

4 Oral statement to Parliament PM statement on living with COVID: 21 February 2022", https://www.gov.uk/government/speeches/pm-statement-on-living-with-covid-21-february-2022

5 '“Gung-ho' living with Covid strategy could backfire and cause more NHS turmoil", The Telegraph, February 18, 2022, Friday 6:00 AM GMT

6 Time to move on from Covid for good", telegraph.co.uk, February 18, 2022, Friday 6:00 AM GMT.

7 Via the LexisNexis database https://advance.lexis.com/

$8 \quad$ Hearts of DARKNESS; New campaign to help rugby players with mental health problems is much needed", The Sunday Times (London) February 19, 2017 Sunday, Edition 1, National Edition.

9 https://idioms.thefreedictionary.com/

10 Cambridge Dictionary https://dictionary.cambridge.org/

11 Cambridge English Thesaurus, Cambridge University Press.

12 Drew P, Holt E. Idiomatic expressions and their role in the organization of topic transition in conversation. In: Everaert M, van der Linden E, Schenk A, Schreuder R, eds. Idioms: Structural and psychological perspectives. Psychology Press, 1995: 117-32.
13 Drew P, Holt E. Complainable matters: The use of idiomatic expressions in making complaints. Soc Probl 1988;35:501-20. doi: 10.2307/800594.

14 "This is what you said about the new Covid-19 restrictions", Oxford Mail, November 29, 2021 Monday.

15 Wetherell M, Potter J. Mapping the language of racism: Discourse and the legitimation of exploitation. Harvester Wheatsheaf, 1992.

16 Private Eye Magazine on Twitter. https://twitter.com/PrivateEyeNews/status/1478687111196950528?t=QhB1NfHKxr2dLqexZWC-Wg\&s=09

17 https://twitter.com/paulrogers002/status/1468717154379960321?t=pj26aKCUNyWFtC3tCJtKNA\&S=09

18 Augoustinos M, LeCouteur A, Soyland J. Self-sufficient arguments in political rhetoric: Constructing reconciliation and apologizing to the Stolen Generations. Discourse Soc 2002;13:105-42. doi: 10.1177/0957926502013001005

19 COVID-19 Response: Living with COVID-19" https://www.gov.uk/government/publications/covid19-response-living-with-covid-19

20 Oral statement to Parliament: PM statement on living with COVID: 21 February 2022 https://www.gov.uk/government/speeches/pm-statement-on-living-with-covid-21-february-2022 